\title{
IMPROVEMENT OF PHYSICAL FITNESS LEARNING RESULT THROUGH METHOD PLAY OF CLASS VIII STUDENTS AT PUBLIC JUNIOR HIGH SCHOOL 5 PALLANGGA IN GOWA DISTRICT
}

\author{
Irfan $^{1}$, Rahmanul Hakim ${ }^{2}$ \\ State University of Makassar \\ singaracayati@ymail.com
}

\begin{abstract}
The purpose of this study is to describe efforts to improve physical fitness learning outcomes through the method of playing on students of class VIII public junior high school 5 Pallangga Gowa District. Approach in this research is qualitative descriptive approach with class action research type. The implementation of this research is focused on two variables, namely the method of play and physical fitness learning outcomes. This research was conducted in public junior high school 5 Pallangga Gowa Regency with research subjects of VIII students amounting to 40 people. Data collection techniques used are observation, test and documentation. Data analysis techniques used are qualitative and quantitative descriptions. Based on the results of the study concluded that learning through the application of play methods can improve physical fitness learning outcomes in grade VIII students. From the analysis result obtained significant improvement from cycle I and cycle II. The result of physical fitness learning in cycle I in the finished category is $37.5 \%$ with the number of students 15 people whereas in cycle II there is an increase in the percentage of student learning outcomes in the complete category of $95 \%$ with 38 students complete.
\end{abstract}

\section{Keywords: Learning Outcomes, Physical Fitness, Playing Methods}

Education as a lifelong process of human development. In Law no. 20 of 2003 on the National Education System (article 1) states that: Education is a conscious and well-planned effort to create an atmosphere of learning and learning process so that students actively develop their potential to have spiritual spiritual power, self-control, personality, intelligence, noble character, as well as the skills needed by them, society, nation and State. Based on the above educational goals, the curriculum of physical education in Junior High School is physical fitness learning, which includes understanding how to get and keep the student body healthy and fit, as well as developing cognitive, and affective aspects / social. Physical fitness needs to be owned by every student because as a provision in living everyday life and the next.

Physical fitness taught in schools is an important part of the effort to shape the character, morality, and social attitudes that become one of the main elements to form the young generation of achievers, qualified and character in order to build the nation and the country towards a better future. Through school fitness learning will affect some aspects of student life such as: (1) students will get how to get and maintain physical fitness, (2) students can move from weak condition to healthier and fitter condition, (3) support skill students in various things for example in learning some branches of sports, and (4) encourage students to be independent, so as to solve all the problems that it faces.

The facts of the observations that have been done show that the problems faced by physical and health education teachers in Public junior high school 5 Pallangga Gowa district associated with learning are as follows: (1) lack of experience and creativity of teachers in the learning process is varied and interesting so that the activity students are reduced so that it affects the way teachers teach in the field that is still like sports education using the method of training and command and minimal updating in learning; (2) the method of delivery of learning material of pemas on students is not delivered in play situation with attention to the characteristics and needs so that students are expected to participate more actively in the process of teaching and learning activities; (3) the lack of teachers' 
creativity in preparing the means of learning (modification of sports equipment) in accordance with curriculum content in an easy and practical way to overcome the limitations of sports infrastructure in schools; (4) the limited number of lessons to provide physical fitness materials in physical education because the allocation of lesson time is only once a week ( $3 \times 40$ minutes), thus affecting the lack of opportunity students to perform a motion skills learned so that student satisfaction is not maximal and learning objectives as well student learning outcomes do not reach Minimum Exhaustiveness Criteria; and (5) teachers are still central to learning activities so that students tend to be passive, ineffective and underachievers in learning because they listen more and practice what the teacher instructs.

Based on the process of analysis of the results of the above observations of teachers physical education and health class VIII in the field, it can be concluded that the learning has not been successful. In order for physical education and health education, especially physical fitness training materials can be successful, it must be created a conducive environment by modifying the tool and creating a learning method that certainly takes into account several factors one of which is the learning activities directed at the characteristics of the students themselves. use of appropriate learning methods can improve efficiency and effectiveness in teaching and learning process. In determining the method of learning, not the purpose that adapts to the method or character of the student, but the method should be a dependent variable that can change and evolve as needed. The effectiveness of the use of methods can occur when there is conformity between methods and all learning components. The more precise the method used by teachers in membelajarkan, is expected to be more effective also the achievement of learning objectives. Of course, other factors must also be considered as teachers, students, situations (learning environment), media and others. Therefore, the functions of the learning method also determine the success or failure of a learning process.

For the purpose of physical and health education to be achieved, the delivery of learning materials to students must be communicated in play situations. Therefore, teachers should be able to develop effective learning, understanding and taking into account the characteristics and needs of students. Characteristics of junior high school students aged 12-15 years, all aspects of human development both cognitive, psychomotor and affective changes. The most striking changes are physical and psychological growth and development and most of them tend to still play but are more challenging. One effort made to realize it is through the method of play. Playing is a fun thing for students, by playing the students do not feel tired or burdened in doing physical activity, but it becomes something fun. The statement is similar to Musfiroh (2008: 1) states play is:

Activities performed on the basis of pleasure and without considering the outcomes and contain elements: (1) fun and exciting for students, 2) encouragement to play emerge from students instead of coercion of others, 3) students do because spontaneous and voluntary, 4) all students participate together according to their respective roles, 5) students apply pretense, or portray something, 6) the students set their own rules, whether the rules are adopted from other people's rules or new rules, 7) students are active, and 8) play is flexible. The elements in the above play activities are important because physical fitness learning is certainly inevitable from the use of modified means of equipment or exercise equipment. Playing in this case involves physical activity that is beneficial to the formation of students' physical fitness in an exercise setting. The desired play is that students have sufficient motion skills, while developing cognitive, physical, and affective / social aspects. Therefore, teachers should be able to develop effective, efficient and interesting learning, in addition to understanding and taking into account the characteristics and needs of students.

\section{METHOD}

The learning and training process for student participants is through play activities, so physical fitness learning must be designed in a playful and competitive atmosphere that is recreative. The process of learning sports education in learning physical fitness designed through play activities, 
of course, not separated by the presence of necessary equipment. Equipment can be modified in the manufacture with a variety of existing equipment, so it can help overcome the limitations of facilities and infrastructure in schools. The framework that has been described above can be described as follows:

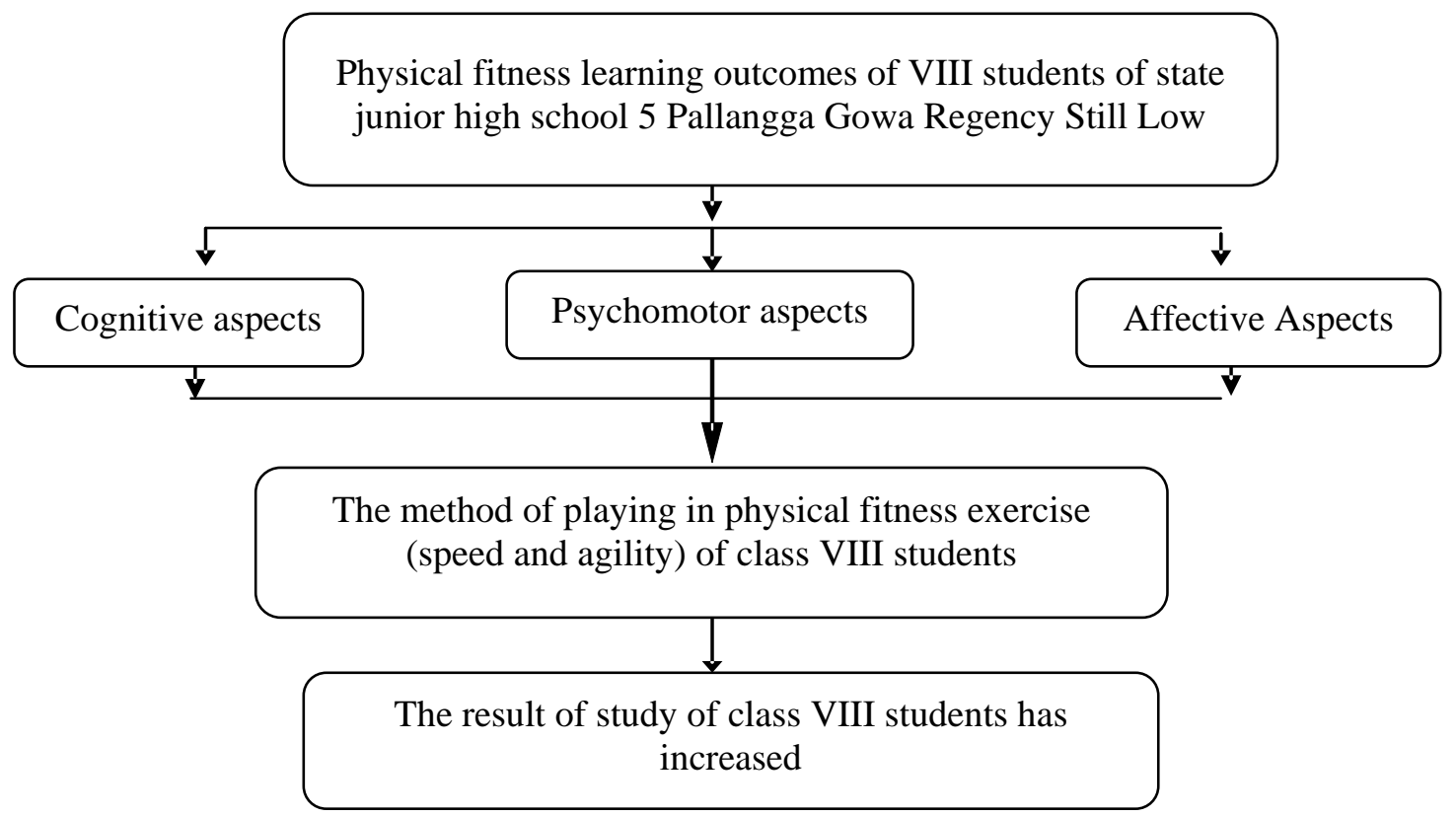

Framework of Thinking

Researchers assume from the various types of physical fitness exercises that have been given to students, both types of these less well-executed exercises and both physical fitness exercises are very important to support sports achievement. In addition, speed and agility are both focused on the motion quickly but there are differences. At speeds only emphasize at moving speeds on the same movement as well as repetitive such as running in place, while the agility in addition to the ability to move quickly also how fast can make changes in body position to perform different movements.

Based on the reasons of the researcher above, then these two exercises will be used as a measure in assessing the students' physical fitness learning outcomes in conducting the research. Researchers assume that both types of physical fitness exercise, can support exercises of physical fitness then using the method of play so that the learning results of physical fitness students can be maximal let alone the implementation of learning is packed in the form of classroom action research. Both forms of the exercise will be clearly described as follows:

1. Speed training

a. Running on the spot

b. Exercise run back and forth

c. Running sideways to the right and left.

2. Exercise Agility

a. Run Shuttle Exercise

b. Basic exercise jump by using tire media

c. Zig Zag Run Training

Type of research applied is Classroom Action Research is planned in several cycles to see the improvement of physical fitness learning outcomes through the method of play with the application of learning aids. Research Setting

The location (setting) of this research is conducted in Public junior high school 5 Pallangga Gowa Regency which is located at Jl. Baso Dg. Mangawing, Poros Paku Pallangga District of Gowa 
Regency of South Sulawesi Province. The study was conducted for two months and began in February to March 2015.

1. Research Subject

Subjects in the implementation of this TOD consists of two parts: (1) VIII students of 40 people to get data about physical fitness learning outcomes through the method of play; and (2) teachers as collaborators, to see the success rate of learning through play methods implemented in the academic year 2014/2015.

Stages in this study form a cycle. Each cycle starts from planning to reflection. The number of cycles depends on whether or not it is required. The action is considered complete if the inner problem has been solved. The research flow, can be displayed as follows:

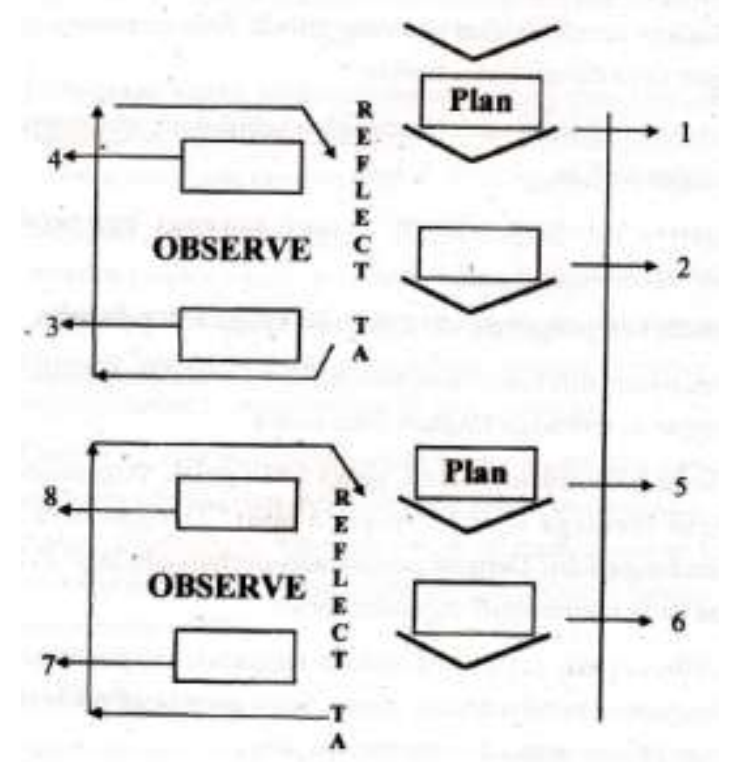

Picture. Spiral Model CLASSROOM ACTION RESEARCH Flow (Sukidin, et al. 2008: 49)

Data collection techniques used in the implementation of Classroom Action Research consists of observations and interviews with the following description:

\section{Observation}

In this research, the observation method is used to obtain data about the students' participation on the material taught by the teacher and the activity done by the teacher during the learning process. The observation sheet used will be filled by observers based on observations made as well as items of statements tailored to the items assessed. The observation sheet provided is the teacher's observation sheet by making observations when delivering the learning materials and student observation sheets made while receiving the learning materials.

2. Test

The test is used to obtain data about students' ability in doing physical fitness exercises conducted by students of class VIII Public junior high school 5 Pallangga Gowa District. Cognitive test (knowledge in the form of multiple choice, stuffing and essay) and psychomotor (performance by looking at the ability to perform physical fitness training)

1. Data Analysis Technique

The data obtained in this research are observation sheet and learning result test.

a. Analysis of observation data sheets: Observational data were obtained at each action to assess any changes in student attitudes in each cycle. This data is presented descriptively on the research results. 
b. Analysis of learning outcomes: Learning outcomes conducted at the end of the meeting are calculated average scores then categorized within the assessment boundaries based on the students' mastery of the subject matter given.

2. Success Indicators

The indicator of the success of the action in this study is if there is an increase in the students' learning outcomes in grade VIII Public junior high school 5 Pallangga Gowa Regency mathematically with the fulfillment of Minimum Exhaustiveness Criteria (Minimum Exhaustiveness Criteria) that is $80 \%$ of students can reach Minimum Exhaustiveness Criteria in the classical that has been determined that is 70 while the average value the average class must reach a predetermined Minimum Exhaustiveness Criteria that is 70.

\section{RESULT}

The initial conditions of the study were measured from observations and performance tests. Observation is used to know student activity (affective) and concept comprehension (cognitive) in physical fitness learning while performance test (psychomotor) is used to know and measure how big of student ability in doing physical fitness before giving action in the form of applying method of play in process of learning that goes on.

The result of observation is the result of learning physical fitness of students obtained through the observation sheet covering affective sphere obtained through observation of student activity during learning and cognitive domain obtained from objective test, and psychomotor domain obtained through performance test. For the affective domain the maximum value is 30 , the maximal cognitive domain of 20 and the psychomotor domain of the maximum value of 50 (the process value 30 and the result value 20) so that the whole value is 100 .

Table 4.4 Learning Outcomes of Physical Fitness Before Getting Action With Playing Methods

\begin{tabular}{|c|c|c|c|}
\hline \multirow{2}{*}{ Aspek } & \multicolumn{2}{|l|}{ Kondisi Awal } & \multirow[b]{2}{*}{ Kriteria } \\
\hline & Persentase $(\%)$ & Jumlah Anak & \\
\hline \multirow{2}{*}{$\begin{array}{l}\text { Hasil belajar kebugaran } \\
\text { jasmani }\end{array}$} & $75 \%$ & 30 & Belum Tuntas \\
\hline & $25 \%$ & 10 & Tuntas \\
\hline
\end{tabular}

Based on the above table, it is concluded that the students' learning outcomes have not been maximized because only $25 \%$ is complete from 40 students. Therefore, an action is taken to improve the learning outcomes of physical fitness through the application of play methods in teaching and learning activities.

\section{Cycle I}

a. Planning Stage

Learning basic physical fitness techniques in the first cycle is done in four meetings. Action planning activities I held on Monday, March 23, 2015. Planning action as follows:

1) The research team conducted a curriculum analysis to find out basic competencies to be delivered to students in physical education, sports and health education.

2) Creating a Lesson Plans (RPP) with reference to the action applied in the TOD is the method of playing for physical fitness learning.

3) Prepare the media necessary to assist learning.

4) Prepare observation sheets or learning observation sheets.

b. Implementation Phase

The implementation of the first cycle action was conducted in four meetings. The first, second and third meetings were held for $2 \times 35$ minutes and the fourth meeting conducted the evaluation test of students' learning outcomes on the cognitive aspect. 


\section{1) First Meeting}

The material on the implementation of the first cycle I meeting held on Saturday, March 25, 2015 is a practice run on the spot for speed training and shuttle run for agility training.

2) The Second Meeting

The material on the implementation of the second cycle action of the second meeting (Wednesday, April 01, 2015) is the practice of physical fitness movements running back and forth (strength training) and jumping with the tire media (agility exercise).

3) Third Meeting

The material on the implementation of action cycle I of the third meeting held on Wednesday, April 08, 2015 is the practice of physical fitness movement running sideways to the right and left (strength training) and ziz-zag run (agility exercise).

4) Fourth Meeting

Implementation of the fourth cycle of the fourth meeting held on Wednesday, April 15, 2015 is the implementation of the assessment to determine the student's activities (affective), conceptual understanding (cognitive) in physical fitness learning and performance test (psychomotor) to know and measure how much students in doing physical fitness.

c. Observation Stage

This stage is the stage where the students observed during the activity. The results of the observations are then analyzed and evaluated the success rate. Further steps are determined for the learning phase of the next cycle. This observation stage consists of two parts, namely observation of the learning process and the results of observation of learning.

The result of physical fitness learning is a combination of affective, cognitive and psychomotor domains. Condition of learning outcomes of students of class VIII in the implementation of physical fitness learning after given the action of cycle I by the method of play can be presented in table 4.8 as follows:

Table 4.8 Learning Outcomes of Physical Fitness After Cycle I Action through Playing Methods

\begin{tabular}{l|l|l}
\hline Aspek & Jumlah & Persentase (\%) \\
\hline Nilai $\leq 70$ & 25 & $62,5 \%$ \\
\hline Nilai $\geq 70$ & 15 & $37,5 \%$ \\
\hline Tuntas Belajar & 15 & $37,5 \%$ \\
\hline Tidak Tuntas Belajar & 25 & $62,5 \%$ \\
\hline Nilai Tertinggi : 82 & 1 & $2,5 \%$ \\
\hline Nilai Terendah : 61 & 2 & $5 \%$ \\
\hline Nilai Rata-rata & 68,2 & \\
\hline
\end{tabular}

Based on the above table, after being given an action, it can be explained that the students' learning outcomes increase compared to the initial condition, which initially at the initial condition only $25 \%$ or 10 completed students, at the end of the first cycle increased to $37.5 \%$ or 15 students thorough while the unfinished reached 25 students or $62.5 \%$ of 40 students. The highest score based on the affective, cognitive, and psychomotor scores achieved by students is 82 and the lowest score is 61 whereas the average score of students is 68.2. Seeing the percentage of achievements, then the target achievement of $60 \%$ at the end of the first cycle has not been achieved. Thus, researchers and collaborators agree to plan for the next cycle. Then an action is prepared to get maximum learning outcomes, considering the achievement target of $80 \%$ has not been achieved.

d. Reflection Stage

Based on the observations on the action of cycle I, researchers and collaborators perform the analysis and reflection as follows: 
1) The number and frequency of meetings in cycle I have shown appropriate results, given the large and varied amount of material delivered as well as the time allocation in teaching a little.

2) Implementation of teaching and learning process has been in accordance with the plan made in the Lesson Plans of Learning (RPP) cycle I.

3) The results of student work on the implementation of the action cycle I showed an increase but has not shown the maximum results.

a) The ability of students in performing skill sets and physical fitness outcomes has shown improvement results compared to the initial conditions, but not yet maximal, so it needs to be improved through the next cycle.

b) Student learning outcomes and activities in physical fitness learning have shown improvement compared to the initial conditions, but not maximal, so it needs to be improved.

Anticipating the weaknesses and shortcomings found during the implementation of the first cycle action, anticipatory steps are prepared, namely:

1) In anticipation of student delays then, the teacher in question will give sanction in the form of questions that have kaitanya with learning materials physical fitness.

2) Teachers should be able to create a conducive learning atmosphere, comfortable and invites students to dare to practice physical fitness exercise as well as possible.

3) Teachers need to change the variation of learning so that students focus more on learning materials

4) To increase students' understanding of physical fitness, the teacher gives copies of physical fitness materials.

5) The heating that originally uses static and dynamic heating will be replaced with a game to attract student participation.

6) To be more effective in the teaching task, the researcher does not cease to warn students to do their duty properly.

7) To facilitate researchers in dividing students in groups or calling students to carry out teaching tasks and facilitate the process of observation then the teacher gave a number of chests.

8) Researchers and collaborators provide rewards for students who can perform a series of physical fitness.

9) To facilitate the process of observation researchers and collaborators assisted by other colleagues.

10) Researchers and collaborators agree to arrange remedial action and repeat materials that are considered not mastered.

\section{Cycle II}

a. Planning Stage

Physical fitness learning in cycle II is done in four meetings. Each meeting consists of one lesson ( 2 x 35 minutes) held on Monday, April 20, 2015. The planning phase in cycle II includes:

1) Create a lesson plan by referring to the action applied in the Truth or Dare, ie the method of playing for the learning of Physical Fitness.

2) Prepare the media needed to assist learning.

3) Prepare observation sheets or learning observation sheets.

b. Implementation Phase

1) First Meeting

The first meeting was held on Wednesday, April 22, 2015. The material on the implementation of action cycle II is the same as in the first cycle action is doing physical 
fitness activities. The basic technique moves to run in this place is the same as the previous meeting, only the distance traveled by students as far as 20 meters. the shuttle run exercise is the same at the previous meeting, only different is the back is done as fast as possible as much as 4-6 times (distance 6-8 meters).

2) The Second Meeting

The second meeting of the implementation of action cycle II was held on Wednesday, April 29, 2015. The material on the implementation of this second cycle action is a repetition of a series of physical fitness activities movement at the previous meeting. How to do a quick run back and forth is not much different from the previous meeting. Added is the students circularly spin for 2 seconds for the first stage, before running and running quickly over a distance of 10 meters and then continue to run back to where it was originally.

3) Third Meeting

The material on the implementation of the third cycle action of the third meeting held on Wednesday, May 13, 2015 is a repetition of the practice of physical fitness movement running sideways to the right and left (speed training) and ziz-zag run (agility exercise). How to do is not much different from the previous meeting. It's just this type of run is done with a distance of about 10 meters, then re-run sideways to the original place. This movement is done more will be better. As for the zig-zag run exercise, same movement at the previous meeting. In this exercise, students run zig-zag run follow the number eight and pass through the barriers of students with long lines in the form of zig-zag lines.

4) Fourth Meeting

Implementation of the second cycle of the fourth meeting held on Wednesday, May 20, 2015 is a meeting that is packed specifically for the assessment to know the student activity (affective) and conceptual understanding (cognitive) in learning physical fitness and performance (psychomotor) is used to know and measure how much students' ability to perform physical fitness.

c. Observation Stage

1) Observation of Learning Process

This step of observation is done by researchers and collaborators during the learning process takes place. In the implementation of action cycle II is still there is a shortage in the implementation of there are still some students that the results and basic techniques of physical fitness is not complete, especially students who laze.

2) Learning Process Observation Results

During the implementation of the second cycle action, the researchers and collaborators do the data retrieval research. The description of the data taken consists of observations; (1) the ability to perform a series of physical fitness and physical fitness outcomes (2) understanding students' concepts of physical fitness and (3) student activity during learning. Condition of learning outcomes of class VIII students in learning physical fitness after given the action cycle II by the method of play is presented in the table as follows:

Table 4.12 Learning Outcomes of Physical Fitness After Cycle II Action through Playing Methods

\begin{tabular}{l|l|l}
\hline Aspek & Jumlah & Persentase (\%) \\
\hline Nilai $\leq 70$ & 2 & $5 \%$ \\
\hline Nilai $\geq 70$ & 38 & $95 \%$ \\
\hline Tuntas Belajar & 38 & $95 \%$ \\
\hline Tidak Tuntas Belajar & 2 & $5 \%$ \\
\hline Nilai Tertinggi : 98 & 1 & $2,5 \%$ \\
\hline
\end{tabular}




\begin{tabular}{l|l|l}
\hline Nilai Terendah : 67 & 1 & $2,5 \%$ \\
\hline Nilai Rata-rata & 86,97 & \\
\hline
\end{tabular}

Source: Appendix 13

Based on the above table, after given the action, it can be explained that the students' learning outcomes increased compared to the first cycle condition that was only $37.5 \%$ or 15 students completed, at the end of the second cycle increased to $95 \%$ or 38 students are complete while the not yet completed the remaining 2 students $(5 \%)$. The highest value of physical fitness learning based on the affective, cognitive and psychomotor values achieved by students in cycle II is 98 and the lowest score is 67 whereas the average value achieved is 86.97 . Seeing the percentage of achievement, then the target achievement of $80 \%$ at the end of cycle II has been achieved. Thus, researchers and collaborators agree not to proceed to the next cycle action because it has obtained the maximum learning outcomes with an achievement target of $80 \%$ achieved.

d. Reflection Stage

Results of data analysis and discussion of researchers with collaborators on the implementation of learning using play methods in cycle II, has shown significant changes. From the analysis, it is known that the students 'level of mastery in the value of physical fitness ability (psychomotor) shows $95 \%$ of students has been completed while in the students' concept of physical fitness (cognitive) has reached $95 \%$ and student activity in learning (affective) has reached $92.5 \%$. With increasing psychomotor domains, cognitive domains and affective domains, the learning outcomes also increase, at the initial condition of the original $25 \%$ or 10 completed students increased at the end of cycle I $37.5 \%$ or 15 students and at the end of the second cycle increased to $95 \%$ or 38 students. This result shows that in cycle II it is above the achievement indicator.

On the basis of the completeness and see the results obtained in the observation data, the learning using play methods implemented in cycle II is said to be successful, so no need to continue in the next cycle.

\section{DISCUSSION}

Classroom action research that has been carried out in the process of physical education learning with physical fitness material through play method can improve students' physical fitness, student activeness, student's excitement and classroom atmosphere becomes better, so the purpose of learning will be easily achieved by optimal through, mastery students on learning materials physical fitness through the method of play.

Learning physical fitness through this play method as a variation of physical fitness learning, but does not reduce the values contained in learning such as self-confidence, responsibility, seriousness and the other. The game in this case as a form of approach towards improving physical fitness.

Based on findings and reflections during cycle I and cycle II, learning to improve fitness through play methods was effective in learning sports and health and able to improve student learning outcomes along with understanding of learning materials. It can be seen from the students 'level of mastery in the value of physical fitness ability (psychomotor) shows $90 \%$ of students have been completed while in the understanding of students' concepts of physical fitness (cognitive) has reached 95\% and student activity in learning (affective) has reached $92.5 \%$. With increasing psychomotor domains, cognitive domains and affective domains, the learning outcomes also increase, at the initial condition of the original $25 \%$ or 10 completed students increased at the end of cycle I $37.5 \%$ or 15 students and at the end of the second cycle increased to $95 \%$ or 38 students .. These results indicate that in cycle II is already above the indicator of achievement. The increase of students' learning 
outcomes on physical fitness enhancement materials through play method achieves $80 \%$ learning completeness level provides evidence that learning to improve fitness through play methods can train students to link their potential.

Physical education learning generally refers not only to values, but the most important of the learning process. In this learning process teachers should make students enthusiastic, happy and active, in following the learning, so that the fitness and health of students can increase. Based on the learning process and the value obtained by students can be said that the learning of physical fitness by the method of playing successfully.

Physical fitness learning with play method gets good response from students. These results indicate that the majority of students are very enthusiastic and more motivated in following physical fitness learning with play methods. This is caused by the play method, the students are more interested, the learning is more varied and not boring, the delivery of the material by the teacher is quite clear, the students have no difficulty in following the game, the students are not too difficult in learning the technique, the test is tested in accordance with the material that has been taught and the classroom atmosphere is fun and the mastery of the material by the teacher is quite good. Musfiroh (2008: 6) points out that play can develop aspects of student development, including "playing for students' cognitive development, playing for socio-emotional development; play for motor development, and play for language / communication development ".

Physical education learning with physical fitness material through play method gives hope to students about the learning where students are more pleased with existing learning element of play, physical fitness learning with play method more easily understood, teacher explanation is quite clear and students feel able to carry out the test with good.

This research has been cultivated and carried out well, however, the researchers feel that there are still many limitations and weaknesses among others: (1) the research is only held in four meetings, the fourth meeting is continued

Taking test scores at once to measure the level of physical fitness takes more time; (2) The games used should be more varied; and (3) the implementation of classroom action research carried out during the extreme weather season which should be dry season in the morning (effective hours).

The limitations and weaknesses that arise in the implementation of this classroom action research is an attempt to improve the learning conditions. This is in line with the opinion of Asrori (2007: 6) which puts the meaning of Classroom Action Research as "a form of reflective research by taking certain actions to improve and improve classroom learning practices in a better quality so that students can get better learning outcomes". Thus, it can be concluded that the ability of students in the mastery of material in this case physical fitness through the method of play can improve physical fitness of students of class VIII Public junior high school 5 Pallangga Gowa District.

\section{CONCLUSION}

Based on data analysis and discussion that have been disclosed, it can be concluded that learning through the application of play method can improve physical fitness learning outcomes in grade VIII students. From the analysis result obtained significant improvement from cycle I and cycle II. The result of physical fitness learning in cycle I in the finished category is $37.5 \%$ with the number of students 15 people whereas in cycle II there is an increase in the percentage of student learning outcomes in the complete category of $95 \%$ with 38 students complete.

\section{REFERENCE}

Asrori, Muhammad. (2007). Classroom action research. Bandung: CV. Prima Discourse Budiningsih, Asri. (2005). Learning and Learning. Jakarta: Rineka Cipta.

Djoko, Pekik Irianto. (2004). Practical Guidelines for Exercising for Fitness and Health. Yogyakarta: ANDI Offset. 
Hartati, Sofia. (2005). The Development of Learning In Early Childhood. Jakarta: Depdiknas. Musfiroh. (2008). Smart through Playing. Jakarta: Grasindo

Purwanto. (2013). Evaluation of Learning Outcomes. Yogyakarta: Student Literature.

Language Center of the Ministry of National Education of the Republic of Indonesia. (2008). Indonesia Dictionary. http://pusatbahasa.diknas.go.id/kbbi/ index.php.

Roji. (2007). Sports and Health Physical Education for Grade VIII junior high school. Jakarta: PT. Erland

Roji and Eva Yulianti. (2014). Sports physical Education and health. Jakarta: Center for Curriculum and Books, Ministry of Education and Culture of the Republic of Indonesia.

Sujiono, Yuliani Nurani. (2009). Basic Concepts of Early Childhood Education. Jakarta: Index.

Sukidin, et al. (2008). Classroom Action Research Management. Jakarta: Insan Cendekia. Sukmadinata, (2010). Educational Research Methods. Bandung: PT. Youth Rosdakarya. RI Law no. 20 Year 2003 on National Education System.

Widiastuti. (2011). Sports Tests and Measurement. Jakarta: PT. Bumi Timur Jaya. 